\title{
14
}

\section{Neoliberalism? That's not how practitioners view public sector reform}

\author{
Peter Shergold and Andrew Podger
}

\begin{abstract}
The Government is establishing an independent review to ensure the APS is fit-for-purpose for the coming decades. The APS needs to be apolitical and professional, agile, innovative and efficient - driving both policy and implementation through coherent, collaborative, whole-of-government approaches. (Independent Review of the APS 2018)

'A clear-eyed and objective look at the Australia Public Service is clearly needed, but we have real concerns that this review will be subservient to neoliberal orthodoxy and the bizarre and damaging policies ... imposed in pursuit of that extreme ideology, said CPSU National Secretary, Nadine Flood. (Donaldson 2018)
\end{abstract}

\section{Introduction}

This chapter is in two complementary parts, bookended by this co-authored introduction and a short co-authored conclusion.

In the first part, Peter Shergold challenges the too-common view of academics and other outside observers that governments, and the public service in particular, have consciously pursued a 'neoliberal' ideological agenda over the last 30 years. The 'neoliberal' tag is not consistently 
defined - indeed, it is rarely defined at all and few who use it appreciate its peculiar history. People do not ever call themselves neoliberal; instead, they only use the term to tag their enemies.

Public servants may recognise the key features of political change that are identified by the academics but would be surprised at their framing as part of a neoliberal agenda. Public servants live in a world of continuous political debate and compromise. Their world is one of iteration. They are not driven by ideological purity, but are schooled in pragmatism; they focus on achievement of results, key performance indicators, value for money. Their role is not to advocate for particular policies - that is the province of elected ministers - but to explain the measures being taken and to implement them. Moreover, behind the scenes there is healthy debate among officials about the reform measures being pursued.

Andrew Podger expands on Shergold's description of the world of public servants by setting out in some detail what the practitioners who have led much of the public sector reform agenda have actually said. Each reform step has been taken pragmatically, to increase efficiency or improve the quality and effectiveness of government programs. At times, the steps have involved unwinding previous actions that had proved unsuccessful but more often they have built on previous steps, as ways to make new incremental improvements were discovered.

The focus of the practitioners is best described as 'management for results'. It is true that the means for achieving results have shifted with more willingness to use market-type mechanisms, and that this was consistent with broader economic policy changes pursued by successive governments in the face of global competition. But changing the means did not mean limiting the role of government or its capacity to achieve the policy objectives governments set, notwithstanding suggestions to the contrary by outsiders claiming a neoliberal agenda.

John Wanna is the exception to the rule: he is the academic outsider who listens to the insiders, is willing to embed himself in public service organisations to observe exactly how they behave, what they say to each other, why they pursue their management reforms. His is still an independent voice, willing to criticise when actions do not meet claimed improvements; and to relate what is happening to scholarly theories of public administration and historical experience, and to international 
experience. It is why he is trusted by practitioners - he understands their business and eschews vague and unsubstantiated typecasting such as the charge of 'neoliberalism'.

\section{The thunder of outside voices shouting: Has the Australian Public Service really become a 'neoliberal' public service?}

\section{Peter Shergold}

\section{Talking to public servants}

The oeuvre of John Wanna's published research on Australian public administration reflects his lifetime interest in how 'bureaucracy has been substantively reformed ... to make it more efficient and effective and to improve its responsiveness to both members and the public' (Wanna, Weller and Keating 2000, 236). He has not always been an admirer of aspects of that process. Indeed, on occasion he has been strongly critical both of the reasons for change and of the manner in which it has been implemented. Always, however, his arguments have been well-informed.

There is a reason for that. Wanna's great academic strength has been his conscious efforts to understand the reform undertaking from the inside. His underlying concern, which his writing has sought to ameliorate, is that 'today's public entrepreneurs are taking part in revolutionary changes but often without recording their experiences' (Wanna, Forster and Graham 1996, x). His unremitting goal has been fully to understand the 'evolving genus of public employees' just as much as the 'inspired few' at the top. Together they have driven 'a conscious and deliberate movement within the Australian public sector' (Wanna, Forster and Graham 1996, 14).

It has not been an easy path for Wanna to tread. As he emphasised back in the mid-1990s, 'such momentous changes are highly controversial and have attracted avid supporters and detractors' (Wanna, Forster and Graham 1996, x). They still do. Wanna's approach, increasingly rare, has been to get himself 'embedded' with public servants as an insider without sacrificing his outsider perspective. He exhibits empathy for the reformers although not necessarily for their goals. 
He worked for a time in the Commonwealth Department of Finance, observing the manner in which the agency performed its functions. He has observed the work of the Australian Public Service Commission from within. In all his research he has talked to public servants about how they go about their business. And, in general, public servants have reciprocated his interest, welcoming the opportunity to converse, be interviewed and even co-author articles. Sometimes he agrees with their arguments. Sometimes he does not. But their views, written or oral, are always taken seriously. They are accorded respect. Public servants are given a voice.

Wanna's strength - and the reason public servants actually read his scholarly work - is that he recognises that a public service is not an anonymous and amorphous institution but a multitude of officials doing their work. In Wanna's sympathetic portrayal, they are people: employees who gather information, establish priorities, test assumptions, share dialogue, seek to persuade others, develop narratives, learn how to anticipate shifting political circumstance and respond to the agenda of the government of the day. To understand the Australian Public Service (APS) requires 'a fair and accurate assessment of the Canberra-based SES ... the non-Canberrabased managers and those often in crucial discretionary positions below the SES' (Wanna 1992, 44).

Even the mandarinate of secretaries, he notes, has always been a far more diverse group than their counterparts in France or the UK. They are:

human beings coping with the pressure of managing careers and
personal lives ... in their careers they were sometimes fortunate,
lucky, exasperated, disappointed, proud of their achievements,
worried that things are getting away from them or becoming
harder to manage. (Wanna, Vincent and Podger 2012, xi)

He understands how they seek to influence the decisions by which public policy is created and executed. He is sensitive to the complex interplay of overt and covert power in which they ply their vocation.

His fascination with how these forces are reflected in organisational structures breathes life into complex issues of policy design, program implementation and regulatory intervention. Without bringing together practitioners and scholars, he asks, how can one truly 'explain the beliefs and ideas local political actors maintained about their own system'? From an anthropological or 'ethno-methodological' perspective, one needs to 
comprehend the 'operational "myths" or belief-systems ... through which actors shape their world and ideas' (Patapan, Wanna and Weller 2005, 245, 247).

I emphasise these qualities not simply to accord respect to the person honoured in this festschrift. I do so because it is a virtue that is relatively uncommon within academia and becoming less so.

Elsewhere, on a number of occasions, I have explored (and bemoaned) the manner in which so much potentially valuable scholarly research gets 'lost in translation' (Shergold 2011). Too rarely does it inform evidence-based policy. In this essay my concern runs deeper. I seek to understand why the fashion in which public servants articulate the need for change, and the manner in which academics critique it, rarely engage. Too often both sides talk past each other. Indeed, it is sometimes hard to countenance that they are talking about the same phenomena. Frequently, the philosophical worldview that frames how university researchers and opinion writers portray the changing nature and purpose of public service employs language and intellectual constructs with which most practitioners do not identify.

The words used by external observers to describe the managerial culture within which public servants operate would almost never be employed by those who are observed. In the late 1980s the evolution of public service in Western democracies was generally portrayed as symptomatic of the emergence of 'new public management', although sometimes the terms 'postmodern' or 'post-bureaucratic' public administration were used as alternatives. These trends - and particularly the outsourcing of service delivery - were seen to give rise to the 'Enterprising State', the 'Contract State' or the 'Hollow State'. The changes were presented as the products (particularly in Australian jargon) of 'economic rationalism' or (in American parlance) of 'new paternalism'. They claimed 'the ground once occupied by the old state-bureaucratic paradigm' (Considine 2001, 5).

Rarely did I hear public servants employ those idioms themselves. Perhaps that is not surprising given that each of the terms tended to convey a pejorative rather than a neutral character. But language moves on. Increasingly, the preferred framework of academic discourse on Australian democracy centres on 'neoliberalism'. Australia's modern political parties, we are told, 'have changed around the dominant paradigm of neoliberalism' (Kefford 2015, 200). And so, too, the world. 'Forget every 
conspiracy theory that you've read' warns one Australian commentator, for 'nothing will prepare you for the nightmare ideology of neoliberalism' (Stinson 2014).

The ideological construct of neoliberalism is used to name and shame. Indeed, it is almost never used by those politicians and public servants who are the objects of the criticism. It has become a swearword dressed up as polemic (Hartwich 2009). It tends to convey a sense of judgemental superiority. It is a term redolent of political decline, societal inequality, decaying administrative standards and rotting ethical foundations. It is 'a lazy term (used only pejoratively)' (Lawson 2018). But what precisely does the term seek to convey? And to what extent have Australian public services really transformed themselves into institutions fit for neoliberal purpose?

\section{The peculiar history of neoliberalism}

The history of economic thought is a fascinating but arcane world. The intellectual roots of ideas shoot, develop and intertwine: the woodland paths get lost in the trees. Concepts rarely have a certain beginning. As they grow and develop, their scholarly proponents reassess and rearticulate different ways of imagining the economic order of the world, as it is or how it might be. A 'school of thought' nearly always turns out to be more complex and internally riven at any given moment than the unifying nomenclature suggests. Over time places, events and personal circumstances create a chronology marked by predictable twists and unexpected turns.

Historical analysis reveals agreements and arguments, amiable consensus and fierce disputation, intellectual consensus and bitter fissures. No sooner is a philosophical position clarified than it morphs into something else, subtly familiar or entirely different. Personal acrimony plays a role. Individuals identify with a position, argue with those who seek to subscribe to or modify it and, not infrequently, end up rejecting the description (and sometime the intellectual substance) of the view attributed to them. The history of ideas is messy.

So it is with neoliberal economics. Its intellectual paradigm has a disputed history complicated by geopolitical diversity. In the late nineteenth century it emerged as a term used by the French economist, Charles Gide, to describe the economic beliefs of an Italian colleague, Maffeo Pantaleoni. 
It indicated a break with the classical liberalism of Adam Smith. It was best espoused perhaps by the Austrian economist Ludwig van Mises and German social market economists such as Eucken, Röpke, Rüstow and Müller-Armack. As the twentieth century progressed, neoliberalism sought to position itself between the polar opposites of laissez-fairism and state control.

A key event, the Walter Lippman Colloquium of 1938, brought together a group of intellectuals who shared a deep-seated resistance to prevailing economic mores and who organised themselves - briefly - around the 'neoliberal project'. They were united, briefly, around the priority of the price mechanism, free enterprise and the benefits of competition (Aalbers 2016, 569).

Unity did not prevail for long. Clashes on political economy and social philosophy soon surfaced. Within the agreed framework of polemical discourse there emerged profound points of intellectual difference. Some proponents believed that there was a need for a strong, impartial and constructivist state to create and supervise the necessary conditions for a competitive market free of monopolistic cartel behaviour ('ordo-interventionism') (Hartwich 2009, vii). Others argued that it was better to leave the competitive market largely unregulated, relying on its intrinsic structural mechanisms to generate the societal information necessary to empower individuals and corporations to make rational economic decisions.

The exemplar of that position, certainly to those critical of the ethos, was Friedrich Hayek and the views he espoused, most particularly in Road to Serfdom (Hayek 1944), and echoed later by Milton Friedman (1962) in Capitalism and Freedom. Hayek's influential but hotly contested proposition was that any centralised control of economic activities by the state was likely to be misused and tended to be associated with political repression. Democracy was best protected by an unfettered market.

Meanwhile, in the US, a group of prominent Americans began to build a body of economic thought that challenged the postwar Keynesian consensus. It is often associated with University of Chicago economists such as George Stigler, Gary Becker and Ronald Coase. The university's doyen, Milton Friedman, initially subscribed to the term neoliberal as a characterisation of his own views. By the late 1960s, however, he had rejected it as a useful descriptor of his intellectual position on monetarism 
and supply-side economics. Nevertheless, opponents continued to draw a strong link between the Chicago School's espousal of limited government intervention and the premises of neoliberal economics.

Then, in the 1970s, an odd transmutation occurred. It essentially transformed a school of economic thought into a marker for ideological confrontation. A group of Spanish-speaking scholars, opposed to the influence of the 'Chicago Boys' on the economic policies associated with General Pinochet's autocratic rule in Chile, identified the enemy they faced as neoliberalism. It was from that circumlocutious genesis that left-leaning English scholars found themselves attracted to the term, predominantly as a means of rejecting its avowed political menace.

And so it has come to pass that in the last 40 years neoliberalism has become a term generally associated with those economic policies that are seen as creating increased inequalities in income, wealth and power. Kean Birch, who has identified at least seven variants of neoliberalism, is indubitably correct in arguing that it is tricky to identify neoliberalism with any one particular school of thought without missing out a whole lot of the story' (Birch 2017). But it is too late: the word has become the intellectual weapon of choice. The more amorphous the concept the greater its power to condemn.

It is a term often identified with the economic policies of 'the apostles of neoliberalism - state withdrawal, and surrender of control of economic factors to the private sector - Margaret Thatcher and Ronald Reagan' (Strangio, 't Hart and Walter 2017). But its pernicious influence stretches beyond 'Thatcherism' and 'Reaganomics', and is applied also to many of the policies pursued by Jimmy Carter and Bill Clinton in the US. It is seen as central to Tony Blair's 'Third Way' and 'Modernising Government' initiatives in the UK. It is the preferred term used to characterise the policies pursued by the 1980s Labour Government of David Lange and the strong deregulatory impulse of 'Rogernomics' in New Zealand. Lange, it is argued, was 'the affable and charming salesman' for a neoliberalism which out-Thatchered Thatcher (Marcetic 2017).

For similar reasons, it has become the common epithet applied by critics to the successive Labor and Liberal governments of Australia led by Bob Hawke, Paul Keating and John Howard and beyond. To opponents, what Paul Kelly (2011) has characterised as the 'March of Patriots' took place to the drumbeat of neoliberalism. Critics are appalled that Kelly, who never 
uses the term, 'commends the neo-liberal political economy that prompts governments to deregulate markets ... to privatise public assets, to impose new obligations on welfare recipients, and to open Australia to global flows of people, goods and finance' (Rowse 2003).

\section{Neoliberalism as political shorthand for horror}

Today, neoliberalism has become largely an expression of political opposition. The provenance of its complex intellectual origins have been lost and its arguments simplified. The term is most often deployed as the object of a rather crude form of sloganeering. In the last 30 years it 'has rapidly become an academic catchphrase' (Boas and Gans-Morse 2009, 138). In its simplest form it represents: 'markets good, government bad' (Jones, Parker and ten Bos 2005). Often it is employed as a pejorative term for 'hyper-capitalism', 'capitalism with the gloves off or 'liberalism ... with a vengeance'. It is 'a catch-all shorthand for the horrors associated with globalization and recurring financial crises' (Jones 2014, 2).

'Much maligned, often misunderstood, neoliberalism is frequently in the eye of the beholder. And that beholder is often a hostile one.' Thus argues Bernard Keane (2018), seeking to explain how Australian politics has gone to hell and dragged us with it. 'Neoliberal', he recognises, 'has become a term of abuse for the left, denoting virtually any economic or fiscal policy disliked by progressives'.

Neoliberalism has emerged, within the treatises of angry academic discourse, as an international phenomenon. It represents 'the contemporary form of capitalism which now dominates the world economy' (Dunlop 2016). It is 'a political project carried out by the corporate capitalist class' since the late 1970s (Harvey 2016). Almost every public policy crisis can be attributed to neoliberal economic principles. From this jaundiced perspective, global financial recession is interpreted as symptomatic of the 'crisis of neoliberal capitalism'.

What was the cause of the disastrous bushfires in Australia 2019-20? The answer: 'It's neoliberalism that lit the fires' (Gibson 2019). And coronavirus? The COVID-19 pandemic is 'exposing the plague of neoliberalism' (Giroux 2020). And climate change? That, too, reveals the destructive assaults waged by neoliberal globalisation on the ecosystem. By contributing to untrammelled environmental degradation, 'the era of neoliberalization also happens to be the era of the fastest mass extinction 
of species in the Earth's recent history' (Harvey 2016, 172). Even the recent moral crisis of Australian cricket reveals neoliberalism's nefarious hand (Williams 2018).

Neoliberalism is the spectre that haunts governments around the globe. From urban water privatisation in Bolivia (Spronk 2007) to the collection of television tax in Bosnia and Herzegovina (Delic 2016), from land conversion in Guyana's gold fields (Canterbury 1977) to timber production in south-eastern Mexico (Klepeis and Vance 2009), from workforce policy in New Zealand (Marcetic 2017; Perry 2007) to welfare consumerism in Denmark (Anderson 2019), from the contamination of water in Ontario (Prudham 2004) to the undermining of municipal unionism in San Francisco and Toronto (Travis 2017; Fanelli 2014) the roots of pernicious public policy can most often be sourced to the worldwide proliferation of neoliberalism.

International institutions and their policy objectives have also been captured. The undermining of public health by the International Monetary Fund (IMF) can be attributed to 'the deadly ideas of neoliberalism' (Rowden 2009). Similarly, the World Trade Organization and the World Bank have attracted excoriating criticism for supposedly representing the vanguard of a particularly vicious brand of neo-liberalism' (Anonymous 2000). All the institutions, it is suggested, have become exponents of the neoliberal agenda (Mentan 2015, 298).

In Australia, Job Network (now jobactive) is also tarred with the same brush. So, too, are welfare reform, health services and aged and community care. Education policy is 'increasingly infused and driven by the logic of profit' (Davidge 2016) inspired by a neoliberal set of financial practices and exchanges (Ball 2012). Australia, from 1975 until today, has been in the grip of 'neo-liberal policy hegemony' (Haworth and Hughes 2015, 122; Lloyd 2008, 40): Richard Denniss (2018b) argues that 'for thirty years, the language of neoliberalism has been applied to everything from environmental protection to care of the disabled'. 'The only issue that matters' in Australia today is 'the galloping inequality, the public squalor and private splendour of a neoliberal deregulated capitalism' (Roberts 2017).

In short, the perceived application of neoliberalism to public policy is now couched almost exclusively in a negative form. The extensive literature suggest that its pernicious influence comes in 'waves', that its manifestation involves 'excesses', and that its effects are 'repressive'. It is portrayed as 
a source of brutal government inaction. Its 'neoliberal penalty' is exhibited in economic inequality and social instability, the increasing insecurity of wage labour and the widening incarceration of the poor. It represents, according to The Handbook of Neoliberalism, 'a seemingly ubiquitous set of market-orientated policies ... being largely responsible for a wide range of social, political, ecological and economic problems' (Springer, Birch and MacLeavy 2016, 2). It is 'the ideology at the root of all our problems' (Monbiot 2016).

\section{The case for the prosecution}

So what, more precisely, do critics of neoliberalism wish to convey? In essence, it is argued, its ethos is predicated upon the superiority of the market and its pursuit has been driven ruthlessly by the exigencies of public government austerity. Government proponents seek to reduce deficits and lower spending. They eschew redistributive polices. They see the social protections of a welfare safety net as a hindrance to economic growth. They imagine that state regulation, especially of the labour and capital markets, produces rigidities. They argue that all sectors of the economy should be opened up to competition. Neoliberalism is symbolised by 'its uncritical worship of free markets and its determinedly wasteful consumerist culture' (Mackay 2014).

Neoliberals as characterised show little interest in constraining the free movement of goods and services across sovereign borders. Nor do they believe that the state should intervene in foreign trade to protect domestic economic enterprises (or their workforces) from global competition. Neoliberals do not wish the state to control international financial markets or, domestically, to establish price controls. They believe that taxation should be reduced to provide an incentive to work and invest. Monetary policy should focus on inflation.

For critics, this ideological bent has had disastrous consequences for citizens. While economic growth has resulted, its benefits have gone overwhelmingly to the privileged. Under the ideological pretence of individual freedom and self-reliance, neoliberals espouse policies that engender increasing inequality of income, wealth and opportunity, and result in ever-greater concentration of economic power. The pursuit of labour market flexibility is a smokescreen for the casualisation and exploitation of paid work. 
Neoliberalism, from this perspective, is defined as blind faith in unrestrained market competition. Its deleterious ambition is to drive 'the extension of the competitive markets into all areas of life, including the economy, politics and society' (Springer, Birch and MacLeavy 2016, 2). It is not just that 'spheres of life are colonized by the market': the state actually creates new markets for commoditised public goods (Meagher, Connell and Fawcett 2009, 333). It is an ethos that is 'privileging market competition over moral considerations' (Hil 2014). The world is imagined as 'a vast supermarket' in which citizens are treated merely as consumers. Indeed, Tom Christensen (2005), assessing critically Norway's move to new public management and privatisation adopts the term 'supermarket state' to characterise the future he fears (Olsen 1988, cited in Christensen 2005, 725).

The Australian version of the neoliberal impulse, it is argued, intends to 're-task' the state into a minimalist form (Weiss 2012). Successive governments under its ideological sway have sought to privatise and commercialise the public sphere by breaking up and selling state assets. They have transferred responsibility for the construction of public infrastructure and delivery of public programs to a contestable environment of outsourced providers.

And neoliberalism is not just reflected in public policy. In pursuit of its goals, neoliberal politicians have undermined the institutional structures of democratic governance and conducted an 'assault against public services and workers' (Fanelli 2014). Everywhere, one can discern a 'pattern of linkage between public service reform and neoliberalism' (Clark 2002, 771). Professional expertise has been undermined. In North America, Europe and Australasia, public administration has been in retreat. Officialdom has been captured. Neoliberalism now stalks the corridors of bureaucratic power. Its agenda has been imposed on society through the 'state project' of new public management.

Indeed, public services are characterised as the institutional means by which governments deliver their supposedly neoliberal agendas. Public servants provide advice to frame the policy discussions of governments, design the programs that give effect to their decisions and deliver (directly or through third parties) the services, payments or regulatory interventions that implement their goals. 
In Australia, it has been proposed, public servants have done much more than be responsive to their political masters (Pusey 1991). They have led the charge. It was the economic rationalists in senior levels of the APS in the 1980s and 1990s who persuaded their ministers to pursue deregulatory neoliberalism. It was departmental secretaries, the 'shadowy but influential figures in determining how Australia is governed', who struck out in a neoliberal direction (Weller 2001). 'Top public servants are the "switchmen" of history', it is posited: 'when they change their minds the destiny of nations takes a different course' (Pusey 1991, 2). Bureaucrats changed their minds and persuaded their political masters to change theirs.

Whether or not Australian public servants were leaders or led, it has been argued that the institutions in which they work have been transformed by ideology. They have become the most significant method by which to 'introduce neoliberalism policies by a kind of organisational coup' (Meagher, Connell and Fawcett 2009, 333). Critics suggest that public service agencies, like the policies they are required to execute, have been made over by a market-oriented ethos.

The private sector has been looked to as a means by which to drive greater efficiency and effectiveness in public administration. Today 'the profitseeking corporation is promoted as the admired model for the public sector' (Connell 2010, 25). A public service agency now functions like a profit-making firm. The structures, operational systems and workplace culture of public services have been given neoliberal guise.

Performance measures have been introduced, by which managers are held accountable for value-for-money results that reflect the economic constraints of budgets rather than the quality of social provision. An audit culture prevails (Sparkes 2013). Neoliberals, by constantly emphasising the need for austerity, have lowered expectations of public administration: for 'the past 30 years, Australians have been told we can't afford high quality public services' (Denniss 2018a). They have sought 'to stigmatize and marginalise ... public bureaucracy in particular, as being outmoded and as functionally and morally bankrupt' (Fournier and Grey 1999, 108).

Meanwhile, it is argued, the avowed commitment of governments to improve service standards has become a neoliberal mechanism by which citizens are transformed into customers. The public as a collective has been replaced by individual consumers accessing specific public 
services. By framing governance and the democratic process in market terms, a political culture has emerged that 'casts citizens as autonomous economic agents, relating to each other and to the state as individual entrepreneurs' (Sparrow 2012a).

Many areas of activity previously undertaken by public servants have been outsourced to the private sector. Most profoundly, the delivery of services to the public has increasingly been 'marketised'. Governments have been repositioned as purchasers rather than providers of public services. There is now a preference to privatise services whenever possible (Hil 2014). A quasi-market is created in which third-party organisations are contracted to deliver government programs. Public administrators, placed in charge of the tender process, are forced to become 'program champions'. The consequence 'is to politicize the senior public service' (Langford and Edwards 2001).

In fact, in Australia it is non-profit civil society organisations that have won most of the tendered contracts for the delivery of human services. This might seem at odds with a neoliberal agenda. Yet, through suspicious eyes, this outcome is portrayed simply as a devious way to take advantage of weaker industrial protections and lower salaries in the community sector (Healy 2009). More importantly, it is presented as a means of coopting non-profits to a subservient role. Australian governments 'have utilized the third sector as a means of quelling political opposition by rendering these community organisations dependent on funding tied to performance and outcome measures set by government' (Van Gramberg and Bassett 2005, 2). The National Disability Insurance Scheme might be hailed as socially progressive but 'what on earth is the NDIS, with its opaque bureaucracies and internal market, if not a neoliberal concoction?' (Harris et al. 2014).

From this perspective, advocacy organisations in the pursuit of government contracts, have been silenced. Keen to hang on to their contracts, they are fearful of criticising government. It is a clever tactic that has 'the effect of institutionalising the neoliberal agenda while quashing political opposition' (Van Gramberg and Bassett 2005, 2). In accepting grants and contracts from governments, community organisations have unwittingly 'supped with the Devil'. 
Commissioning service provision from external providers has also been presented as driven by 'an agenda of de-professionalization' in which public sector knowledge is outsourced to less-trained staff (Malin 2017). This move has a 'gendered' impact, because work is moved from a predominately female public sector to a predominately male private sector. Even initiatives framed around enhanced community support for volunteerism or greater citizen participation have actually 'further entrenched neoliberalism' (Fawcett and Hanlon 2009). One must not be beguiled, we are warned. This is a world in which the public evocation of social purpose can nearly always be revealed as driven by nefarious motivation.

\section{The case that falls on deaf ears}

The power of neoliberal motivation to explain this perceived restructuring of public service goes almost unchallenged in peer-reviewed scholarly journals. It has pervaded much of the social science literature in Australia. Many academics see successive Australian governments as pursing a neoliberal agenda since at least the 1980s, although some believe that their own location within a 'neoliberal university' mutes their voice for public policy change (Cox 2018).

They identify 'new public management' as a structural manifestation of that ideological predisposition to diminish the role of public administration. There has been a conscious effort 'to stigmatise and marginalise ... public bureaucracy ... as being outmoded and as functionally and morally bankrupt' (Fournier and Grey 1999, 108). 'Applying the lessons learned from neo-liberalism', Australian public services underwent 'a huge and self-conscious project of reinvention' by moving away from procedural governance and enterprising the state' (Considine 2001, 2). Neoliberalism was 'the ideological driver behind the practices and policy of New Public Management' (Fawcett and Hanlon 2009; Roberts 2015).

The contrast in perspective from those active in public life could not be starker. Politicians (rarely) and public servants (almost never) see themselves as subscribers to neoliberalism. Most public policy management textbooks do not employ the term. Pick up the major tomes on Australian public administration - the most recent edition of The Australian Policy Handbook (Althaus, Bridgman and Davis 2017), perhaps, or Policy Analysis in Australia (Head and Crowley 2015) - and there is not a single reference 
to neoliberal goals. Nor, indeed, is there in Public Sector Management in Australia, to which Wanna was a contributing editor (O'Faircheallaigh, Wanna and Weller 1999).

Politicians, too, either avoid the term or, equally likely, have never come across it. In some 1,400 pages of text relating to his own political life and that of the Liberal's greatest leader, Robert Menzies, John Howard never uses the term neoliberal (although he does acknowledge en passant the influence of 'so-called neo-conservatives' close to George Bush). Nor did Bob Hawke reference the term in his biography. Indeed Hawke, questioned about his supposed 'ideological predilection' for neoliberal policies emphatically rejected the proposition: in his view he laid down a new direction for the social democrats (Swan 2017). Nor do the standard biographies of Paul Keating employ the word. Keating himself emphasised that 'we are not "-ists" and we do not believe in "-isms"' (Ramsay and Battin 2005). Nor does Julia Gillard's biography mention neoliberalism. Indeed, it is not a term used by any of the national campaign directors of either of Australia's two major political parties. Nor does it appear in either of David Lange's two New Zealand memoirs.

It is a similar story at the state level. To critics, neoliberalism was 'characterised by the sweeping privatisations that premier Bob Carr championed in NSW' (Sparrow 2012b). By recasting the entire social world on market lines, Carr's government strenuously led the 'neoliberal project' in Australia. The premier, in a scathing indictment, was 'Carr(ion)' (Sparrow 2012b). This is not the world as seen by Carr. 'The prevailing ideologies?' scoffed the ex-premier: 'sorry, too grand a word. Let's call it the prevailing ethos, way of thinking' (Carr 2018).

By contrast, Kevin Rudd as prime minister did use the term. But he did so only to attack his political opponents as foot-soldiers of the neoliberal enemy. In a wide-ranging paper on the global financial crisis, Rudd sought to present his election as a seismic turning point in political history. He offered himself up as the prime minister who would bring to an end the 30-year 'triumph of neoliberalism - that particular brand of free-market fundamentalism, extreme capitalism and excessive greed which became the economic orthodoxy of our time' (Rudd 2009). On reflection, he believed he delivered. Rudd remembers his response to the global financial crisis as a direct attack on the prevailing neoliberal orthodoxy' (Rudd 2018). 
None of this bone-pointing at others has offered protection to Rudd from the righteous indignation of critics. Labour politicians are adjudged to have been 'supporters of the neoliberal agenda since the Hayden leadership period' (Marsh 2006). In spite of attempts to shake off the legacy, Rudd's government is seen to represent 'continuity in neoliberal thought and policy'. Indeed, it is 'a kind of wild irony' that 'Rudd denounced neoliberalism, shortly before his government introduced a raft of neoliberal measures' that were implemented by Treasurer Swan (Meagher, Connell and Fawcett 2009, 333). In short, those who are keen to direct attention to the neoliberal garb of their political opponents, find that academic writers often drape them in the same attire. The emperors wear clothes but not of their own choosing.

Australian public servants, who have served at senior levels in successive neoliberal government regimes, do not employ the term at all. They do not utter the word in their speeches or writing. Indeed, to the best of my memory, I have not heard neoliberalism mentioned at any ANZSOG (Australia and New Zealand School of Government) seminar or Institute of Public Administration Australia conference that I have attended over the last 25 years. Enter it as a keyword in the search engine of the Australian Public Service Commission website and, yielding no results, it asks you to check the spelling. Similarly, the NSW Public Service Commission site reports ' 0 results for neoliberalism' (before quickly asking visitors for feedback on the quality of the site).

The failure of senior public servants to identify with the ideological concept for which critics often hold them responsible seems passing strange. Yet it is a particular manifestation of a far deeper phenomenon. Neoliberalism may be 'the idea that swallowed the world' (Metcalf 2017) but it has done so in the most curious of ways. The idiom is generally used now only by those who stridently oppose its avowed consequences: 'People do not call themselves neoliberal; instead they tag their enemies with the term' (Hall and Lamont 2013, xvii). Those who used to identify with the term have vanished. It has become the economic philosophy that dare not speak its name. Silently, its opponents warn us, it is everywhere capturing governments and altering the structure and ethos of the public services that provide advice to them.

There are two obvious reasons why Australian public servants (and the governments they serve) rarely, if ever, identify themselves as neoliberal in orientation. Although I have sought to put flesh on the bones of contention, 
the meaning of the term has considerable ideological fluidity. Neoliberal is most often used to identify enemies, while implicitly signalling the virtue of its critics' own philosophical and ethical credentials.

Moreover, academic strictures on the application of neoliberal theory tend to be couched in the language of contemporary social science. The scholarly narrative of neoliberal criticism is replete with discursive politics, gendered assumptions, sociocultural logic, market commodification of public value, desocialisation of identity, reappropriation of community, privileging of power and exploitation of a 'precariat' class. Sometimes, in a footnote, there is genuflection before the structuralism and hermeneutics of Michel Foucault. That language increasingly permeates the Australian Journal of Public Administration: a recent insightful article on the public policies of bushfire safety was couched in terms of 'the valorisation of hegemonic masculinity' (Reynolds and Tyler 2018, 529). These terms, properly defined, have purpose and meaning but they are not manners of speech that create resonance with most practising public administrators. They widen the gap between the insider and the outsider, between the observation and the observer.

Nor does academic discourse capture public servants' perceived reality. Most would at once recognise the key features of political change that are identified but would be surprised at their framing as part of a 'neoliberal agenda'. Public servants live in a world of continuous political debate but - in part as a consequence - necessary compromise. Their world is one of iteration. Shiny new policies are inevitably tarnished by the need for political negotiation. Second-best solutions to wickedly complex policy conundrums are seen as better than no solutions at all. They are not driven by ideological purity. Nor, they sense, are the ministers they serve.

In fact, a few critics of Australian neoliberalism somewhat grudgingly recognise that political purpose is in practice inconsistent and extraordinarily varied. They acknowledge that in some cases the emphasis on enhanced market-orientation has been counterbalanced by continued commitment to fair and equitable service. Some accept that there is 'no single model of public service reform associated with neoliberal ideological realignment' (Clark 2002). As a special issue of the Australian Journal of Sociology admitted, neoliberal concepts:

have not quite swept all before them in Australian human services ... the achievements of reform efforts are partial ... [and they] have not been entirely successful in replacing other norms and rationalities. (Meagher, Connell and Fawcett 2009, 335) 
In fact, Australia's structural reform policies are a hybrid (Fabian and Breunig 2018).

Academic defenders of the 'Hawke legacy' suggest that 'Hawke never went as far in flirting with neo-liberalism as the Liberal Party did' (Johnson 2009, 7). To some on the centre-left of politics, the views of Hawke (and Keating, Rudd and Gillard) can be distinguished from those of the 'extreme' neoliberal, John Howard. But to others this is simply a false demarcation: party differences 'are not, in fact sides in any meaningful sense but separate cheeks on the same derriere' (Denniss 2018b).

Critics often portray this 'failure' to achieve doctrinal purity as attributable to political opposition and public resistance. They also suggested that political conviction is undermined by self-interested cynicism. While neoliberal language is used to extol the virtues of small government, many of its conservative proponents are actually happy to expend public funds on their own political preferences: they are not ideologues for the simple reason that they 'lack the consistency and strength of principle to warrant the title' (Denniss 2018b). They find themselves brought undone by the rent-seekers of crony capitalism, spruiking government intervention (Keane 2016). Indeed, some argue that it is now conservative politicians, not progressives, that are moving away from market-dominated policies (Bornstein 2017). On such grounds, Richard Denniss postulates that 'neoliberalism is dead'. He argues that Australian politicians of the right have lost confidence in the market and are increasingly attracted to state intervention (Denniss 2018a). But that remains a minority position. Most critics counter that such perspectives do not 'fully appreciate just how deep the market ethos runs in Australian politics' (King 2018). In the eyes of most Australian critics, neoliberalism is alive and well both among politicians and the public servants who work for them.

\section{So, what did the practitioners say?}

\section{Andrew Podger}

It is time, in John Wanna's words, that we 'tried to allow the actors at the time to present the issues in their own words' (Wanna, Ryan and $\mathrm{Ng} 2001$, xi). He suggested that we should be willing to listen to how 'public servants, government employees, politicians, advisers ... provided their own assessments of the changes taking place in the public sector' (O’Faircheallaigh, Wanna and Weller 1999, v). 
Peter Shergold explores above why 'the fashion in which public servants articulate the need for change, and the manner in which academics critique it, rarely engage'. He focuses particularly on the current popular framework of academic discourse that centres on 'neoliberalism'. Let me complement Peter's thesis by referring to the articles and speeches by public servants over the last four decades, a wealth of material in the 1980s and 1990s though sadly more Spartan over the last decade or so.

I should add that practitioner frustration with academics has not been limited to the academics' criticisms of public sector reform. There has been from time to time a denigration of the APS itself with little regard, if any, to facts about the people involved or the work they do. Ian Castles, known within the APS at the time as the most rigorous of academic practitioners, wrote a major rejoinder to criticisms by Donald Horne and Hugh Stretton when Castles was secretary of the Department of Finance defending the record of Australia's civil service and demonstrating by the examples of Treasury secretaries that, unlike many overseas civil services, ours is not dominated by a privileged social class (Castles 1987).

Practitioners' words about reform, not surprisingly, reflect their pragmatic focus. They also demonstrate the particular attributes of public sector reform in Australia from the 1980s: steady, incremental change with occasional punctuations of major measures, but no one big-bang development and few major reversals. These attributes, and the emphasis on pragmatism rather than ideology, have always been highlighted by John Wanna (e.g. Wanna, Kelly and Forster 2000, 311).

This, however, has not stopped other academics from claiming through each stage of Australia's reform process that officials as well as governments have pushed a particular right-wing agenda; many did not concede that the reforms would (and did) lead to improvements in management and public sector efficiency and effectiveness without undermining its fundamental roles.

\section{0s reforms}

The emphasis in the 1980s was on improving efficiency and effectiveness. The genesis of the reforms lay in both the Coombs Royal Commission (RCAGA 1976) and the Reid Report (Review of Commonwealth Administration 1983) that helped to shape the Hawke Government's approach to public expenditure and public sector management 
(ALP 1983). David Shand, before he joined the Department of Finance, welcomed the Hawke Government's statements on Reforming the Public Service and Budget Reform, noting the cautious approach in the latter document and the emphasis on pilot studies including through the Financial Management Improvement Program (FMIP) (Shand 1984).

Shand, together with Malcolm Holmes and under Pat Barrett's leadership within Ian Castles's Finance department, helped shape the FMIP and related management reforms. Following the 1987 machinery of government changes, which both improved cabinet processes and facilitated greater devolution of management authority, Barrett publicly encouraged wide action within line departments to take advantage of the reforms to improve administrative performance (Barrett 1988).

Mike Keating, who replaced Castles as head of Finance in 1987, clarified the objectives of the reforms (Keating 1988):

- to assist the elected government to choose how it wishes to allocate resources best to satisfy its policy objectives

- to improve the effectiveness, equity and efficiency of programs delivered by the public sector directed at meeting these objectives

- to focus the necessary tight restraint in budget outlays on areas where effectiveness, equity and efficiency criteria justify reductions, and embodied in the first three

- to improve the public service as a place to work.

Keating later coined the term 'managing for results' as the underlying basis for the 1980s reforms (Keating 1990).

Academic criticism in the 1980s employed 'managerialism' as the pejorative term for the reforms (Yeatman 1987; Painter 1988; Considine 1988). John Paterson, a senior Victorian public servant, challenged the criticism head-on (Paterson 1988), addressing each of the charges made by one leading critic and declaring firmly that:

- the administrative reforms were not ideologically driven

- no evidence had been presented to support charges of:

- an internal climate being more masculine than in the past

- the quality of work downgraded

- probity declined 
- accountability to the parliament, the general public or those aggrieved by bureaucratic decisions being less

- fairness given less weight, or access of minorities or the disadvantaged to public service positions downgraded.

Paterson's assessment, albeit not scientific, was that none of these charges hold.

During this stage of public sector reform, the language of the practitioners could never be described as 'neoliberal'. Practitioners did not emphasise the use of markets: indeed, Paterson made no mention of competition or markets. Even the government's 1986 statement about reforms to government business enterprises and statutory authorities made no mention of privatisation. Only general references were made to the impact of global competition and that the public sector was not immune from competitive pressures by some public servants (e.g. Keating 1989). These implied that the managerialist agenda complemented the government's wider economic agenda, which embraced global competition by reducing protection, floating the Australian dollar and beginning to deregulate the labour market. This, of course, is entirely consistent with Keating's earlier emphasis that the reforms were explicitly intended to ensure the public service was responding to the elected government's priorities.

It is true, nonetheless, that the reforms during the 1980s consciously shifted the emphasis in public administration from processes and legal language to performance in terms of results and the economic language of prices, efficiency and effectiveness.

\section{Early 1990s}

After a mostly positive report on the FMIP by a parliamentary committee (Australian Parliament 1990), public service practitioners began to take stock of the wider reform agenda. A major evaluation was undertaken for the Management Advisory Committee (Task Force on Management Improvement 1992), led by Vic Rogers from the Department of Social Security (see also Rogers 1992, 1993). While concluding that further effort was needed to take advantage of the reforms, particularly in the area of human resources management, the evaluation found significant improvements in efficiency and effectiveness, that productivity growth in the APS as a whole had been high, and that the reforms had improved the focus on clients and the quality of services (Sedgwick 1994). 
The reform agenda was evolving at that time, with increasing emphasis being paid to the role of markets and competition to improve efficiency as much of the responsibility for financial management was devolved to agencies. Graham Evans, secretary of the Department of Transport and Communications (created in 1987), described his portfolio's reform agenda highlighting the importance of government business enterprises' competitiveness and explaining the department's use of business-type measures such as corporate planning (Evans 1992). John Mellors, a deputy secretary, then secretary of the Department of Administrative Services, described the achievements and challenges from reforms to the common services provided by his department, starting with user pays then user choice of provider and then more commercial approaches to service provision (Mellors 1993, 1996). Mike McNamara and I, then in Defence, described how the department was using competition to drive efficiencies in a wide range of logistical services through the Commercial Support Program (Podger 1994; McNamara 1996). More broadly, the running costs reforms from the 1980s were allowing agencies to determine when contracting out might be more efficient than internal provision of corporate services, and the Department of Finance's procurement rules set out processes for fair competition based on value for money. The reform measures were far more than rhetorical; they involved a cultural change in the management of public moneys, improving value for money by reducing overheads so resources could be focused more on public programs, and paying more attention to program effectiveness.

The shift to greater emphasis on markets and competition was also occurring at the state government level. Sue Vardon in South Australia described the challenges and directions of reform in that state following the collapse of the State Bank (Vardon 1994). Victoria, which had also experienced a financial crisis, restructured its public hospital system introducing a purchaser/provider arrangement to drive efficiencies, led by John Paterson (who had become director-general of the Health Department) and Stephen Duckett. Meredith Edwards, a deputy secretary in the Department of the Prime Minister and Cabinet (PM\&C), also examined international trends in using the competition paradigm to reinvent the work of government (Edwards 1996).

As with the 1980s reforms, these further administrative reforms complemented the wider economic reforms being pursued not only by the Commonwealth Government but also by the states, as illustrated by the Council of Australian Governments' Competition Policy (COAG 1995). 
The underlying purpose of these reforms was to increase productivity in both the private and public sectors, so as to improve Australian living standards.

Academic criticism of the reforms in this period again assumed that the public service practitioners had their own ideological agenda. Michael Pusey led the attack, claiming that 'economic rationalists' in the public service had had an undue influence over the government and, as a result, 'a nation-building state' had 'change(d) its mind' (Pusey 1991). Wanna was among the few academics to dispute the Pusey thesis, his review of Pusey's book opening with the comment that 'Kicking the Canberra can is obviously alive and well' (Wanna 1992). Fred Argy, by then retired from the APS (he had previously been head of the Economic Planning Advisory Committee and a senior Treasury official), wrote a more gentle review nonetheless firmly rejecting Pusey's central thesis of the government and its advisers being against government intervention and insensitive to social welfare and distribution considerations, highlighting Pusey's failure to refer to the actual writings of senior practitioners (Argy 1992).

Mike Keating, then secretary of PM\&C, later felt it necessary to publicly reject the by then widespread characterisation of policy formulation in the last decade as captured by 'neo-classical economic rationalists', noting the critics failed to define an economic rationalist and, 'more importantly, offer little understanding of exactly what has occurred, nor the forces at work' (Keating 1994). It is hard to see how the policies of the previous decade (at least at Commonwealth level), including in the areas of social security, health financing and higher education, or the public management changes that accompanied them, could be viewed then (or now) as in any way rolling back the state or reducing its emphasis on equity.

\section{Later 1990s and early 2000s}

Following the election of the Howard Government in 1996, more emphasis was placed on competition and the use of market-type mechanisms in public administration. As through the earlier phases of reform, this reflected in part the government's wider economic reform agenda, in this case a major influence was its controversial agenda to extend labour market reform. 
Also, there was growing interest in the quality of services provided to the public. Earlier reforms included service charters to ensure that performance was not measured simply in terms of financial efficiency but also in terms of responsiveness to clients. But the next stage of reform began also to emphasise choice by service 'customers', a 'growing issue' according to Mike Keating and one requiring the development of purchaser/provider administrative arrangements (Keating 1996). By this time, I had become secretary of the Department of Health and Family Services; I referred to this issue and how it might be used to shift the health system's orientation away from providers to patients, and promote better service quality, improving health outcomes (e.g. for people with chronic conditions) as well as efficiency (Podger 1997, 1998). While there was a shared desire to see the public service adopt a more outwards focus, there was also an internal debate about the appropriate term for those receiving services ('clients' or 'customers' or 'citizens').

Perhaps the most significant development in this context was the creation of the Job Network replacing the former Commonwealth Employment Service. This involved the employment department paying providers of employment services (for profit and non-profit organisations and, for a time, a public sector provider) to deliver services to unemployed people based on their performance in getting their clients into jobs, and allowing the clients some choice about their provider of services. The establishment of Centrelink also signalled a strengthened emphasis on those receiving welfare payments and services, improving coordination and responsiveness.

Academic critics claiming a neoliberal agenda might find some limited evidence as some practitioners began to express developments in language that seemed to assume the public sector should embrace private sector practices much more broadly than had been done under earlier reforms. Stephen Bartos (a deputy secretary in Finance) advocated that 'every service of government is potentially open to competition' (Bartos 1998), and there was some suggestion of a 'Yellow Pages' philosophy in Finance at the time (that any activity that could be found in the Yellow Pages should be shifted from the public sector and subject to competition). Peter Boxall (secretary of Finance) and Len Early (another Finance deputy) also advocated more business-like approaches right across the public sector (Boxall 1998; Early 1998), a view continued to be expressed by Boxall after his retirement (Boxall 2012). 
All three attracted some criticism from within the APS, perhaps best illustrated by $S$ R Kelleher (a pseudonym for an anonymous public servant), who warned that the allocative powers of markets do not invariably work in the interests of the overall good of the community, and noted the views of past APS leaders that the role of the public service has changed over time 'in degree, not kind' (Kelleher 1998). My strong suspicion is that most public service leaders at the time continued to take a strongly pragmatic approach to reform, eschewing the pockets of ideology that occurred. Indeed, many were continually emphasising the importance of public service values in this period. Peter Shergold (then public service commissioner) noted that traditional values were being retained under the public service reforms being introduced, albeit with more emphasis on performance (Shergold 1997). The values were articulated and placed in the new legislation (Public Service Act 1999 [Cth]).

Mike Keating, after his retirement, perhaps expressed the most widely held view among the practitioner reformers of the 1990s in his book, Who Rules? How Government Retains Control of a Privatised Economy (Keating 2004). In it he argues that 'the shift to marketization largely represents an attempt by government to enhance or restore their power to achieve economic and social objectives, while minimising any loss of efficiency' (Keating 2001, 5); and that 'while marketization may have changed the instruments and policies of governments, governments can still govern: they still command power to determine a course of action and achieve their objectives' (Keating 2004, 12).

\section{Practitioner views since 2000}

The importance of the APS Values was constantly highlighted by the APS Commission (Podger 2002; APSC 2003a, 2003b), emphasising that the ends do not always justify the means, and that traditional values of nonpartisanship, impartiality and professionalism remain paramount. The APS Commission also published a report documenting the Australian reforms at both Commonwealth and state/territory levels (APSC 2003c), describing the focus on results and the use of competition. Written for an international audience (at the request of the Commonwealth Association of Public Administration and Management), it presented practical examples of improvements in efficiency and effectiveness that other Commonwealth countries might consider, whatever their political orientation; there was no material that could be considered ideological. 
Sue Vardon, then CEO of Centrelink, also published an article on possible international implications of Australian public sector reforms (Vardon 2001); Centrelink was later widely acknowledged as a successful reform (Halligan and Wills 2008).

Some modifications were introduced to the earlier reforms (now seen as moves from new public management to new public governance) to give more emphasis to implementation issues and to whole-of-government management (MAC 2004), but most of the framework of the earlier reforms continued, including the emphasis on managing for results and focusing on clients.

Fewer public speeches and published articles by senior practitioners have appeared since the early 2000s (more's the pity), but valedictory speeches by departing secretaries provide a valuable source of senior practitioners' views. They reveal that senior public servants continue to come from a diverse range of backgrounds, both social and academic (Wanna, Vincent and Podger 2012) and are not characterised either by privilege or a neoliberal, economic education. There is a common emphasis on serving the public interest (e.g. Briggs 2012), distinguishing between the role of the public sector from that of the private sector, and focusing on the long term (e.g. Borthwick 2012).

While some continue to emphasise global competitive pressures (e.g. Henry 2012), none could be characterised as implying any particular ideological position. Some provide constructive criticisms about aspects of the reform agenda. I myself questioned attitudes towards freedom of information (Podger 2012), while Patricia Scott expressed unease about the changing role of ministerial advisers (Scott 2012) and Peter Varghese expressed concern about the quality of policy advising (Varghese 2017). Other more recent speeches by secretaries build on the reforms of earlier eras. Mike Mrdak emphasises the importance of value for money in public infrastructure investment (e.g. Mrdak 2018), Steven Kennedy identifies the trend to more tailored services to meet individual needs and preferences (Kennedy 2018), Martin Parkinson highlights the importance of innovation in the public sector (Parkinson 2018, 2019), and Heather Smith emphasises the importance of taking advantage of new technology and recognising its likely impact on the way government does its business (Smith 2019). 


\section{Internal debates}

Notwithstanding the occasional flourish in Peter Shergold's speeches and writings, the tone of most practitioners' public statements has been overwhelmingly pragmatic with an emphasis, dully, on efficiency and effectiveness. This may have disguised the extent of internal debate about the reforms of the last 30 years. On occasion the internal debates have been revealed publicly.

In 1999, I admitted before a Senate Estimates Committee the problems the Health Department was struggling with in implementing accrual accounting. Subsequently, I warned that 'expectations about the benefits have been raised excessively' (Podger 2001, 18), a view shared by many colleagues. Allan Hawke was steadfast in his opposition to the introduction of performance-based pay, which, he argued forcefully, was inimical to public service culture and bad for employee morale (Hawke 2012).

Pat Barrett was highly critical of the appropriation of the term 'customer' to the delivery of public services. Barrett thought the term 'client' 'conveys more about the notion of mutual obligations and relationships, and less about the act of purchasing, which act, of course, includes a decision not to purchase' (Barrett 1999, 4). Shergold publicly argued that the term 'citizen' conveys a better sense of the reciprocated balance of rights and responsibilities that exist between the public beneficiary and the state benefactor (Shergold 2006). I held a similar view; also, I was particularly critical of the practice of some colleagues to refer to their ministers as their 'primary customers' (a view I later published [Podger 2009]).

Another translation of private sector language to public sector management was also debated internally. I said in 2000:

I must admit to continued unease about departmental secretaries being seen as CEOs. Our relationship to ministers, the government and the Parliament is fundamentally different from the relationship between a private sector CEO and the Board ... our role in the Australian democratic system sets the public service apart. (Podger 2000)

The term 'chief executive' appeared in the Financial Management and Accountability Act 1997 (Cth), which applied to departments, but a number of colleagues felt, as I did, that the term was inappropriate. This was not to deny the lessons that could be learned from private sector experience in such areas as project, risk, finance and human resource management. 
There was also vigorous debate about the degree to which the public service should be responsive to the government of the day (and, correspondingly, about its degree of independence). The internal debate became public after I retired from the APS when I publicly argued that the incentives established by secretary appointment and termination processes, and secretary performance pay, was affecting the way advice was (and was not) being provided (Podger 2007). Shergold, still secretary of PM\&C at the time, counter-argued that courage was a matter of character not tenure (Shergold 2007). A subsequent secretary of PM\&C, Terry Moran, encouraged a greater degree of independence (Advisory Group on Australian Government Administration 2010) and the term 'responsive to the Government' was omitted from the APS Values when they were revised in 2013 (though this still appears in the Commissioner's Directions under the Public Service Act), and significant changes were made to secretary arrangements. This important and healthy debate clearly continues both within the APS and publicly.

\section{Conclusion}

The practitioners' perspectives of reforms since the 1980s emphasise the reforms' pragmatism: they do not reveal any ideological agenda but focus on enhancing the capacity of democratically elected governments to set strategic directions and clarify their policy objectives, while also improving the efficiency and effectiveness of administration in delivering the results the government desires.

Perhaps some of the academic critiques we challenge are in part affected by a spillover of political decisions and administration of policy by bureaucrats. Perhaps also, as Pat Weller (1991) suggests, practitioners' pragmatism is not entirely value-free. But from our direct experience, it is not ideological or pursued in order to supplant the elected government's own philosophy and priorities. And there have been, and continue to be, healthy internal debates.

The language of the practitioners in explaining the reforms has been economics-oriented, reflecting in large part the priority successive governments have given to economic policies. This also reflects some of the principles of the economics discipline that professional public administrators (and governments) must not ignore. Importantly, the use of such language and principles should not be seen to reflect a particular 
view of the role (or size) of government or of the distribution of income and wealth in the community. Rather it reflects concern to make the most from limited resources, to recognise rent-seekers and ensure support is focused on those genuinely in need, and to enhance the public good and limit the distortions of market failures.

If there is a legitimate charge of APS practitioners having a particular and common outlook it would most likely align with some of the original liberal economists (and moral philosophers) from the eighteenth and nineteenth centuries rather than the so-called neoliberals of the late twentieth century. As Ian Castles wrote in 1986 as the first wave of new public management reforms began in Australia, those economists were the radicals of their day, not the conservatives: they were opposed to slavery, keen to improve the wellbeing of workers and the poor, concerned about those suffering from the potato famine in Ireland, supported universal, publicly funded education and the rights of women to contraceptive advice (republished in Castles 2015). Castles's essay, while not explicitly saying so, demonstrated that liberal economics can be employed to maximise the efficiency and effectiveness of government in achieving whatever the policy preferences of the elected government may be, including a progressive agenda.

APS practitioners would never accept the charge of being 'neoliberal' if that necessarily implies support for a lesser role for government or a more unequal distribution of income and wealth. Personal views on these issues among practitioners undoubtedly vary. All those we know or have known believe in a substantial role for government, while leaving to the elected government the right to determine exactly what that role should be and the consequences for income and wealth distribution.

Equally, APS practitioners seem constantly to have had to defend themselves against mostly ill-defined academic criticisms of 'managerialism', 'economic rationalism' and more recently 'neoliberalism'. This is not to deny considerable room for legitimate debate about whether reform measures have been taken too far or involved unintended consequences (or indeed have not gone far enough or have gone backwards). But that debate needs to be based on evidence and to take into account the firsthand experience of the practitioners: the approach John Wanna has always epitomised. 


\section{References}

Aalbers, M. B. 2016. 'Regulated deregulation'. In S. Springer, K. Birch and J MacLeavy (eds) Handbook of Neoliberalism. New York: Routledge.

Advisory Group on Australian Government Administration. 2010. Ahead of the Game: Blueprint for the Reform of Australian Government Administration. Canberra: Department of Prime Minister and Cabinet.

Althaus, C., P. Bridgman and G. Davis. 2017. The Australian Policy Handbook. Crows Nest: Allen \& Unwin.

Anderson, J. G. 2019. 'Denmark: The welfare state as a victim of neoliberal economic failure?' In S. Olafsson, M. Daly, O. Kangas and J. Palme (eds) Welfare and the Great Recession: A Comparative Study. Oxford: Oxford University Press. doi.org/10.1093/oso/9780198830962.003.0011.

Anonymous. 2000. 'The IMF and the World Bank: Puppets of the neoliberal onslaught'. The Thistle 13(2).

Argy, F. 1992. 'Book review: Michael Pusey, Economic Rationalism in Canberra: A Nation-building State Changes its Mind. Economic Papers 11(1): 83-90. doi.org/10.1111/j.1759-3441.1992.tb00033.x.

Australian Labor Party (ALP). 1983. Labor and Quality of Government. 1983 election policy statement. R. Hawke and G. Evans. Canberra: Australian Labor Party.

Australian Parliament. 1990. Not Dollars Alone: Review of the FMIP. Report of the House of Representatives Standing Committee on Finance and Public Administration. Canberra: Australian Government.

Australian Public Service Commission (APSC). 2003a. APS Values and Code of Conduct in Practice: A Guide to Official Conduct for APS Employees and Agency Heads. Canberra: Australian Government.

Australian Public Service Commission (APSC). 2003b. Embedding the Values. Canberra: Australian Government.

Australian Public Service Commission (APSC). 2003c. Australian Experience of Public Sector Reform. Canberra: Australian Government.

Ball, S. J. 2012. 'Show me the money! Neoliberalism at work in education'. Forum 54(1): 27. doi.org/10.2304/forum.2012.54.1.23.

Barrett, P. 1988. 'Emerging management and budgetary issues: The view from the centre'. Canberra Bulletin of Public Administration 54(May): 52-57. 
Barrett, P. 1999. 'A more systematic approach to effective decision-making for better outcomes or results'. Address to the Institute of Public Administration Australia Conference, Canberra, 10 March. Available at: www.anao.gov.au/sites/ default/files/Barrett_a_more_systematic_approach_to_effective_decision $\% 20$ making_for_better_outcomes_or_results_1999.pdf?acsf_files_redirect.

Bartos, S. 1998. 'Competitive tendering and contracting'. Canberra Bulletin of Public Administration 88(May): 63-64.

Birch, K. 2017. 'What exactly is neoliberalism?' The Conversation, 3 November. Available at: theconversation.com/what-exactly-is-neoliberalism-84755.

Boas, T. C., and J. Gans-Morse. 2009. 'Neoliberalism: From new liberal philosophy to anti-liberal slogan'. Studies in Comparative International Development 44: 137-161. doi.org/10.1007/s12116-009-9040-5.

Bornstein, J. 2017. 'Just as neoliberalism is finally on its knees, so too is the left'. The Guardian, 25 February.

Borthwick, D. 2012. 'As if for a thousand years - the challenges ahead for the APS'. In J. Wanna, S. Vincent and A. Podger (eds) With the Benefit of Hindsight: Valedictory Reflections from Departmental Secretaries, 2004-2011. Canberra: ANU Press. doi.org/10.22459/WBH.04.2012.10.

Boxall, P. 1998. 'Outcomes and outputs: The new resource management framework'. Canberra Bulletin of Public Administration 88(May): 39-43.

Boxall, P. 2012. 'Reflections of an "unabashed rationalist"'. In J. Wanna, S. Vincent and A. Podger (eds) With the Benefit of Hindsight: Valedictory Reflections from Departmental Secretaries, 2004-2011. Canberra: ANU Press. doi.org/10.22459/WBH.04.2012.11.

Briggs, L. 2012. 'The boss in the yellow suit - leading service delivery reform'. In J. Wanna, S. Vincent and A. Podger (eds) With the Benefit of Hindsight: Valedictory Reflections from Departmental Secretaries, 2004-2011. Canberra: ANU Press. doi.org/10.22459/WBH.04.2012.16.

Canterbury, D. C. 1977. 'The impact of neoliberalism on labour in Guyana: A case from the Caribbean'. Labour, Capital and Society 30(2): 260-289.

Carr, B. 2018. Run for Your Life. Melbourne: Melbourne University Publishing.

Castles, I. 1987. 'Facts and fantasies of bureaucracy'. Canberra Bulletin of Public Administration 53(December): 35-45. 
Castles, I. 2015. 'Economics and anti-economics'. In A. Podger and D. Trewin (eds) Measuring and Promoting Wellbeing. Canberra: ANU Press. doi.org/ 10.22459/MPW.04.2014.04.

Christensen, T. 2005. 'The Norwegian state transformed?' West European Politics 28(4): 721-739. doi.org/10.1080/01402380500216641.

Clark, D. 2002. 'Neoliberalism and public service reform: Canada in comparative perspective'. Canadian Journal of Political Science 35(4): 771-793. doi.org/ $10.1017 /$ S0008423902778438.

Connell, R. 2010. 'Understanding neoliberalism'. In S. Braedley and M. Luxton (eds) Neoliberalism and Everyday Life. Montreal: McGill-Queen's Press.

Considine, M. 1988. 'The corporate management framework as administrative science: A critique'. Australian Journal of Public Administration 47(1): 4-18. doi.org/10.1111/j.1467-8500.1988.tb01042.x.

Considine, M. 2001. Enterprising States: The Public Management of Welfare-toWork. Cambridge: Cambridge University Press.

Council of Australian Governments (COAG). 1995. Competition Principles Agreement. Canberra: Council of Australian Governments.

Cox, E. 2018. 'The changing politics of feminist academics'. Australian Journal of Public Administration 77(4): 525-528. doi.org/10.1111/1467-8500.12321.

Davidge, G. 2016. Rethinking Education through Critical Psychology: Cooperative Schools, Social Justice and Voice. Milton Park: Taylor and Francis. doi.org/ $10.4324 / 9781315676159$.

Delic, V. 2016. 'Dangers of neoliberalism for public services'. Mediacentar_Online, 12 August. Available at: www.media.ba/en/magazin-novinarstvo/dangersneoliberalism-public-services.

Denniss, R. 2018a. 'The big con: How neoliberals convinced us there wasn't enough to go around'. The Guardian, 4 June. Available at: www.theguardian. com/australia-news/2018/jun/04/the-big-con-how-neoliberals-convincedus-there-wasnt-enough-to-go-around.

Denniss, R. 2018b. 'Dead right: How neoliberalism ate itself and what comes next'. Quarterly Essay 70: 1-80.

Donaldson, D. 2018. 'APS review a neoliberal stitch-up, says CPSU'. The Mandarin, 7 May. Available at: www.themandarin.com.au/92303-aps-review-a-neoliberalstitch-up-says-cpsu/. 
Dunlop, T. 2016. 'The "small government" sucker punch'. ABC News, 10 March. Available at: www.abc.net.au/news/2016-03-10/dunlop-the-small-governmentsucker-punch/7234168.

Early, L. 1998. 'The changing role of the public service'. Canberra Bulletin of Public Administration 88(May): 60-62.

Edwards, M. 1996. 'Competition and the public sector'. Canberra Bulletin of Public Administration 81(October): 31-38.

Evans, G. 1992. 'Managing policy and organisational change in the transport and communications portfolio'. Canberra Bulletin of Public Administration 70(October): 1-21.

Fabian, M. and R. Breunig. 2018. 'Market v government? In fact, hybrid policy is the best fit for the 21 st century'. The Conversation, 4 July. Available at: theconversation.com/market-v-government-in-fact-hybrid-policy-is-the-bestfit-for-the-21st-century-98560.

Fanelli, C. 2014. 'Neoliberal urbanism and the assault against public services and workers in Toronto, 2006-2011'. Briefing, 7 March. Articulo - Journal of Urban Research. Available at: journals.openedition.org/articulo/2380.

Fawcett, B. and M. Hanlon. 2009. “"The return to community”: Challenges to human service professions'. Journal of Sociology 45(4): 435. doi.org/10.1177/ 1440783309346474.

Fournier, V. and C. Grey. 1999. 'Too much, too little and too often: A critique of du Gay's analysis of enterprise'. Organization 6(1): 107-128. doi.org/ $10.1177 / 135050849961005$.

Friedman, M. 1962. Capitalism and Freedom. Chicago: University of Chicago Press.

Gibson, S. 2019. 'It's neoliberalism that lit the fires'. Overland 237, 21 November. Available at: overland.org.au/2019/11/its-neoliberalism-that-lit-the-fires/.

Giroux, H. A. 2020. 'The COVID-19 pandemic is exposing the plague of neoliberalism'. Truthout, 7 April. Available at: truthout.org/articles/thecovid-19-pandemic-is-exposing-the-plague-of-neoliberalism/.

Hall, P. A., and M. Lamont (eds). 2013. Social Resilience in the Neoliberal Era. Cambridge: Cambridge University Press.

Halligan, J. and J. Wills. 2008. The Centrelink Experiment. Canberra: ANU Press. doi.org/10.22459/CE.12.2008. 
Harris, S. P., O. Randall, K. R. Fisher and R. Gould. 2014. 'Human rights and neoliberalism in Australian welfare to work policy'. Disability Studies Quarterly 34(4): 1-27.

Hartwich, O. M. 2009. Neoliberalism: The Genesis of a Political Swearword. Occasional Paper 114. St Leonards: The Centre for Independent Studies.

Harvey, D. 2016. 'Neoliberalism is a political project'. Interview in Jacobin, 23 July. Available at: www.jacobinmag.com/2016/07/david-harvey-neoliberalismcapitalism-labor-crisis-resistance.

Hawke, A. 2012. 'The paradox of performance pay'. Sydney Morning Herald, 1 May. Available at: www.smh.com.au/public-service/the-paradox-of-performancepay-20120430-1xtys.html.

Haworth, N. and S. Hughes. 2015. 'The ILO, Greece, and social dialogue in the aftermath of the GFC'. In S. McBride, R. Mahon and G. W. Boychuk (eds) After '08: Social Policy and the Global Financial Crisis. Vancouver: University of British Columbia Press.

Hayek, F. A. 1944. The Road to Serfdom. Chicago: University of Chicago Press.

Head, B. and K. Crowley. 2015. Policy Analysis in Australia. Bristol: Policy Press. doi.org/10.1332/policypress/9781447310273.001.0001.

Healy, K. 2009. 'A case of mistaken identity: The social welfare professions and new public management'. Journal of Sociology 45(4): 403. doi.org/10.1177/ 1440783309346476.

Henry, K. 2012. 'The opportunities, challenges and policy responses for the Australian economy'. In J. Wanna, S. Vincent and A. Podger (eds) With the Benefit of Hindsight: Valedictory Reflections from Departmental Secretaries, 2004-2011. Canberra: ANU Press. doi.org/10.22459/WBH.04.2012.15.

Hil, R. 2014. 'In defence of social service that puts the needs of people first'. The Conversation, 23 April. Available at: theconversation.com/in-defence-ofsocial-service-that-puts-the-needs-of-people-first-24568.

Independent Review of the APS. 2018. 'Terms of reference'. Independent Review of the APS. Available at: www.apsreview.gov.au/about.

Johnson, C. 2009. 'The Hawke government and consensus'. In G. Bloustien, B. Comber and A. Mackinnon (eds) The Hawke Legacy. Adelaide: Wakefield Press.

Jones, C., M. Parker and R. ten Bos. 2005. For Business Ethics. New York: Routledge. doi.org/10.4324/9780203458457. 
Jones, D. S. 2014. Masters of the Universe: Hayek, Friedman, and the Birth of Neoliberal Politics. Princeton: Princeton University Press.

Keane, B. 2016. 'Neoliberalism is fine, but what we have is crony capitalism'. Crikey, 27 April. Available at: www.crikey.com.au/2016/04/27/keane-neoliberalismfine-crony-capitalism.

Keane, B. 2018. The Mess We're In: How Our Politics Went to Hell and Dragged Us with It. Crows Nest: Allen \& Unwin.

Keating, M. 1988. 'Managing change in the public sector'. Canberra Bulletin of Public Administration 55(June): 59-63.

Keating, M. 1989. 'Quo vadis? Challenges of public administration'. Australian Journal of Public Administration 48(2): 123-131. doi.org/10.1111/j.14678500.1989.tb02206.x.

Keating, M. 1990. 'Managing for results in the public interest'. Australian Journal of Public Administration 49(4): 387-398. doi.org/10.1111/j.1467-8500.1990. tb01984.x.

Keating, M. 1994. 'The role of government economists'. Canberra Bulletin of Public Administration 77(December): 1-7.

Keating, M. 1996. 'Past and future directions of the APS: Some personal reflections'. Australian Journal of Public Administration 55(4): 3-9. doi.org/ 10.1111/j.1467-8500.1996.tb02552.x.

Keating, M. 2001. 'National development and the APS'. Canberra Bulletin of Public Administration 101(September): 26-29.

Keating, M. 2004. Who Rules? How Government Retains Control of a Privatised Economy. Sydney: Federation Press.

Kefford, G. 2015. All Hail the Leaders: The ALP and Political Leadership. North Melbourne: Australian Scholarly Press.

Kelleher, S. R. 1998. 'A look at the view from the Department of Finance and Administration'. Canberra Bulletin of Public Administration 89(August): 4-7.

Kelly, P. 2011. The March of Patriots: The Struggle for Modern Australia. Melbourne: Melbourne University Press.

Kennedy, S. 2018. 'National conference: What's next?' In Institute of Public Administration Australia (ed.) IPAA Speeches 2017. Canberra: Institute of Public Administration Australia. 
King, R. 2018. 'Paths to a brighter tomorrow'. Weekend Australian Review, 8-9 September.

Klepeis, P. and C. Vance. 2009. 'Neoliberal policy and deforestation in southeastern Mexico: An assessment of the PROCAMPO program'. Economic Geography 79(3): 221-240. doi.org/10.1111/j.1944-8287.2003.tb00210.x.

Langford, J. and M. Edwards. 2001. New Players, Partners and Processes: A Public Sector Without Boundaries. Canberra: National Institute for Governance.

Lawson, D. 2018. 'Review: Adam Smith: what he thought, and why it matters by Jesse Norman — defending him from his critics'. The Sunday Times, 8 July. Available at: www.thetimes.co.uk/article/review-adam-smith-what-he-thoughtand-why-it-matters-by-jesse-norman-a-model-of-enlightenment-8zx909p5g.

Lloyd, C. 2008. 'Australian capitalism since 1992: A new regime of accumulation?' Journal of Australian Political Economy 61: 31-56.

Mackay, H. 2014. The Good Life: What Makes a Life Worth Living. Melbourne: Macmillan.

Malin, N. 2017. 'Developing an analytical framework for understanding the emergence of de-professionalisation in health, social care and education sectors'. Social Work \& Social Sciences Review 19(1): 66-162. doi.org/10.1921/ swssr.v19i1.1082.

Management Advisory Committee (MAC). 2004. Connecting Government: Whole of Government Response to Australia's Priority Challenges. Canberra: Australian Public Service Commission.

Marcetic, B. 2017. 'New Zealand's neoliberal drift'. Jacobin, 15 March. Available at: www.jacobinmag.com/2017/03/new-zealand-neoliberalisminequality-welfare-state-tax-haven.

Marsh, I. 2006. Political Parties in Transition. Alexandria: Federation Press.

McNamara, M. 1996. 'Contestability and incentives'. Canberra Bulletin of Public Administration 81(October): 7-9.

Meagher, G., R. Connell and B. Fawcett. 2009. 'Neoliberalism, new public management and the human service professions: Introduction to the special issue'. Journal of Sociology 45(4): 331-338. doi.org/10.1177/ 1440783309346472. 
Mellors, J. 1993. 'The commercialisation of common services provided by the Department of Administrative Services: Outcomes and emerging issues'. Australian Journal of Public Administration 52(3): 329-338. doi.org/10.1111/ j.1467-8500.1993.tb00285.x.

Mellors, J. 1996. 'Competitive tendering and contracting'. Canberra Bulletin of Public Administration 81(October): 3-6.

Mentan, T. 2015. Unmasking Social Science Imperialism: Globalization Theory As A Phase Of Academic Colonialism. Bamenda, Cameroon: Langaa RPCIG. doi.org/10.2307/j.ctvh9vxhh.

Metcalf, S. 2017. 'Neoliberalism: The idea that swallowed the world.' The Guardian, 18 August. Available at: www.theguardian.com/news/2017/ aug/18/neoliberalism-the-idea-that-changed-the-world.

Monbiot, G. 2016. 'Neoliberalism - The ideology at the root of all our problems'. The Guardian, 15 April. Available at: www.theguardian.com/books/2016/ apr/15/neoliberalism-ideology-problem-george-monbiot.

Mrdak, M. 2018. 'Secretary series address'. In Institute of Public Administration (ed.) IPAA Speeches 2017. Canberra: Institute of Public Administration.

O’Faircheallaigh, C. S., J. Wanna and P. Weller. 1999. Public Sector Management in Australia: New Challenges, New Directions. Second edition. South Yarra: Macmillan Education.

Painter, M. 1988. 'Editorial: Public management: Fad or fallacy?' Australian Journal of Public Administration 47(1): 1-3. doi.org/10.1111/j.1467-8500.1988. tb01041.x.

Parkinson, M. 2018. '2017 address to the Australian Public Service'. In Institute of Public Administration (ed.) IPAA Speeches 2017. Canberra: Institute of Public Administration.

Parkinson, M. 2019. '2018 address to the Australian Public Service'. In Institute of Public Administration (ed.) IPAA Speeches 2018. Canberra: Institute of Public Administration.

Patapan, H., J. Wanna and P. Weller (eds). 2005. Westminster Legacies: Democracy and Responsible Government in Asia and the Pacific. Sydney: UNSW Press.

Paterson, J. 1988. 'A managerialist strikes back'. Australian Journal of Public Administration 47(4): 287-295. doi.org/10.1111/j.1467-8500.1988. tb01072.x. 
Perry, L. J. 2007. 'Neoliberal workplace reforms in the Antipodes: What impact on union power and influence?' Australian Review of Public Affairs 8(1): 19-46.

Podger, A. S. 1994. 'Partnering: The Defence view'. Australian Journal of Public Administration 53: 43. doi.org/10.1111/j.1467-8500.1994.tb01856.x.

Podger, A. S. 1997. 'The charter of government performance and government service charters'. Canberra Bulletin of Public Administration 84(May): 32-37.

Podger, A. S. 1998. 'Managing performance: Experience and directions in the Department of Health and Family Services'. Canberra Bulletin of Public Administration 89(August): 88-92.

Podger, A. S. 2000. 'The new Public Service Act and the commitment to values'. Canberra Bulletin of Public Administration 97: 22-25.

Podger, A. S. 2001. 'Keynote address: Reforms and their significance'. Canberra Bulletin of Public Administration 99(March): 14-20.

Podger, A. S. 2002. 'Whole of government innovations and challenges'. Canberra Bulletin of Public Administration 61(2).

Podger, A. S. 2007. 'What really happens: Departmental secretary appointments, contracts and performance pay in the Australian Public Service'. Australian Journal of Public Administration 66(2): 131-147. doi.org/10.1111/j.14678500.2007.00524.x.

Podger, A. S. 2009. The Role of Departmental Secretaries: Personal Reflections on the Breadth of Responsibilities Today. Canberra: ANU Press. doi.org/10.22459/ RDS.06.2009.

Podger, A. S. 2012. 'My fortunate career and some parting remarks'. In J. Wanna, S. Vincent and A. Podger (eds) With the Benefit of Hindsight: Valedictory Reflections from Departmental Secretaries, 2004-2011. Canberra: ANU Press. doi.org/10.22459/WBH.04.2012.02.

Prudham, S. 2004. 'Poisoning the well: Neoliberalism and the contamination of municipal water in Walkerton, Ontario'. Geoforum 35(3): 343-359. doi.org/ 10.1016/j.geoforum.2003.08.010.

Pusey, M. 1991. Economic Rationalism in Canberra: A Nation-Building State Changes its Mind. Cambridge: Cambridge University Press.

Ramsay, T. and T. Battin. 2005. 'Labor Party ideology in the early 1990s: Working Nation and paths not taken'. Journal of Economic and Social Policy 9(2): 1-13.

Review of Commonwealth Administration. 1983. Review of Commonwealth Administration (the Reid Report). Canberra: Australian Government. 
Reynolds, B. and M. Tyler. 2018. 'Applying a gendered lens to the stay and defend or leave early approach to bushfire safety'. Australian Journal of Public Administration 77(4): 529-541. doi.org/10.1111/1467-8500.12268.

Roberts, J. M. 2015. New Media and Public Activism: Neoliberalism, the State and Radical Protest in the Public Sphere. Policy Press Scholarship Online. doi.org/ 10.1332/policypress/9781447308225.001.0001.

Roberts, J. M. 2017. 'Neoliberalism, neoclassical economics, twinkle-toes Turnbull and a New Year's resolution'. Pearls and Irritations, 29 December. Available at: johnmenadue.com/jerry-roberts-neoliberalism-neoclassicaleconomics-twinkle-toes-turnbull-and-a-new-years-resolution.

Rogers, V. 1992. 'Performance improvement in the Australian Public Service retrospect and prospects'. Australian Journal of Public Administration 51(4): 416-420. doi.org/10.1111/j.1467-8500.1992.tb01088.x.

Rogers, V. 1993. 'Australian Public Service reform: Managing a 1990s-style inquiry'. Australian Journal of Public Administration 52(4): 371-375. doi.org/ 10.1111/j.1467-8500.1993.tb00290.x.

Rowden, R. 2009. The Deadly Ideas of Neoliberalism: How the IMF Has Undermined Public Health and the Fight Against AIDS. New York: Zed Books.

Rowse, T. 2003. 'The social democratic critique of the Australian settlement'. In J. Hocking and C. Lewis (eds) It's Time Again: Whitlam and Modern Labor. Melbourne: Circa Publishing.

Royal Commission into Australian Government Administrations (RCAGA). 1976. Final Report (the Coombs Report). Canberra: Australian Government.

Rudd, K. 2009. 'The global financial crisis'. The Monthly, February. Available at: www.themonthly.com.au/issue/2009/february/1319602475/kevin-rudd/ global-financial-crisis.

Rudd, K. 2018. The PM Years. Sydney: Macmillan.

Scott, P. 2012. 'Our custodial role for the quality of advisory relations at the centre of government'. In J. Wanna, S. Vincent and A. Podger (eds) With the Benefit of Hindsight: Valedictory Reflections from Departmental Secretaries, 2004-2011. Canberra: ANU Press. doi.org/10.22459/WBH.04.2012.12.

Sedgwick, S. T. 1994. 'Evaluation of management reforms in the Australian Public Service'. Australian Journal of Public Administration 53(3): 341-347. doi.org/10.1111/j.1467-8500.1994.tb01474.x.

Shand, D. A. 1984. Canberra Bulletin of Public Administration 11(2): 77-78. 
Shergold, P. 1997. 'Ethics and the changing nature of public service'. Australian Journal of Public Administration 56(1): 119-124. doi.org/10.1111/j.14678500.1997.tb01247.x.

Shergold, P. 2006. From 'Frank and Fearless' to 'Fumbling and Forgetful'? The Perceived Decline of the Australian Public Service. London: Menzies Centre for Australian Studies.

Shergold, P. 2007. 'What really happens in the Australian Public Service: alternative view'. Australian Journal of Public Administration 66(3): 367-370. doi.org/10.1111/j.1467-8500.2007.00546.x.

Shergold, P. 2011. 'Seen but not heard'. Australian Literary Review, 4 May.

Smith, H. 2019. 'Doing policy differently: Challenges and insights'. In Institute of Public Administration (ed.) IPAA Speeches 2018. Canberra: Institute of Public Administration.

Sparkes, A. C. 2013. 'Qualitative research in sport, exercise and health in the era of neoliberalism, audit and new public management'. Qualitative Research in Sport, Exercise and Health 5(3). doi.org/10.1080/2159676X.2013.796493.

Sparrow, J. 2012a. 'Protests and the hollowing of democracy'. Overland, 19 September. Available at: overland.org.au/2012/09/protests-and-thehollowing-of-democracy/.

Sparrow, J. 2012b. 'So it's Carr(ion)'. Overland, 5 March. Available at: overland. org.au/2012/03/so-its-carrion/.

Springer, S., K. Birch and J. MacLeavy (eds). 2016. Handbook of Neoliberalism. New York: Routledge.

Spronk, S. 2007. 'Roots of resistance to urban water privatization in Bolivia: The "new working class", the crisis of neoliberalism, and public services'. International Labour and Working-Class History 71(Spring): 8-28. doi.org/ 10.1017/S0147547907000312.

Stinson, S. 2014. 'A country under siege: A brief history of neoliberalism in Australia'. Australian Independent Media Network, 28 June. Available at: theaimn.com/country-siege-brief-history-neoliberalism-australia/.

Strangio, P., P. 't Hart and J. Walter. 2017. The Pivot of Power: Australian Prime Ministers and Political Leadership, 1949-2016. Melbourne: Melbourne University Publishing. 
Swan, W. 2017. 'The Hawke-Keating agenda was Laborism, not neoliberalism, and is still a guiding light'. The Guardian, 17 May. Available at: www.theguardian. $\mathrm{com} /$ commentisfree/2017/may/14/the-hawke-keating-agenda-was-laborismnot-neoliberalism-and-is-still-a-guiding-light.

Task Force on Management Improvement. 1992. The Australian Public Service Reformed: An Evaluation of a Decade of Management Reform. Canberra: Australian Government.

Travis, S. 2017. 'What is neoliberalism?' San Francisco Examiner, 25 May.

Van Gramberg, B. and P. Bassett. 2005. Neoliberalism and the Third Sector in Australia. Working paper 5/2005. Melbourne: Victoria University.

Vardon, S. 1994. 'The next steps in public management: A South Australian view'. Australian Journal of Public Administration 53(3): 355-363. doi.org/ 10.1111/j.1467-8500.1994.tb01477.x.

Vardon, S. 2001. "Exporting the APS": The international impact of APS innovations'. Canberra Bulletin of Public Administration 101(September): 30-34.

Varghese, P. 2017. 'Parting reflections'. In Institute of Public Administration Australia (ed.) Twelve Speeches 2016. Canberra: Institute of Public Administration Australia.

Wanna, J. 1992. 'No minister: "Economic rationalism in Canberra: A nationbuilding state changes its mind" by Michael Pusey'. Book review in Australian Law Review February: 43-44.

Wanna, J., J. Forster and P. Graham (eds). 1996. Entrepreneurial Management in the Public Sector. South Yarra: Macmillan Education.

Wanna, J., J. Kelly and J. Forster. 2000. Managing Public Expenditure in Australia. St Leonards: Allen \& Unwin.

Wanna, J., C. Ryan and C. Ng. 2001. From Accounting to Accountability: A Centenary History of the Australian National Audit Office. Crows Nest: Allen \& Unwin.

Wanna, J., S. Vincent and A. Podger (eds). 2012. With the Benefit of Hindsight: Valedictory Reflections from Departmental Secretaries, 2004-2011. Canberra: ANU Press. doi.org/10.22459/WBH.04.2012.

Wanna, J., P. Weller and M. Keating (eds). 2000. Institutions on the Edge? Capacity for Governance. Crows Nest: Allen \& Unwin. 
Weiss, L. 2012. 'The myth of the neoliberal state'. In C. Kyung-Sup, B. Fine and L. Weiss (eds) In Developmental Politics in Transition: The Neoliberal Era and Beyond. London: Palgrave Macmillan.

Weller, P. 1991. 'Financial management reforms in government: A comparative perspective'. Australian Journal of Public Administration 67(November): 9-17.

Weller, P. 2001. Australia's Mandarins: The Frank and the Fearless? Crows Nest: Allen \& Unwin.

Williams, R. 2018. 'Flannelled fools who bend rules'. Weekend Australian Review, 29-30 December.

Yeatman, A. 1987. 'The concept of public management and the Australian state in the 1980s'. Australian Journal of Public Administration 46(4): 339-356. doi.org/10.1111/j.1467-8500.1987.tb02578.x. 
This text is taken from Politics, Policy and Public Administration in Theory and Practice: Essays in Honour of Professor John Wanna, edited by Andrew Podger, Michael de Percy and Sam Vincent, published 2021 by ANU Press, The Australian National University, Canberra, Australia.

doi.org/10.22459/PPPATP.2021.14 